\title{
IAMJ
}

INTERNATIONAL

AYURVEDIC

MEDICAL JOURNAL

Review Article

ISSN: 2320-5091

Impact Factor: 6.719

\section{ANALYSIS OF NIDANAS ON ASRIGDHARA WITH SPECIAL REFERENCE TO PATHOPHYSIOLOGY OF ABNORMAL UTERINE BLEEDING}

\author{
Noor Fathima ${ }^{1}$, Mamatha K.V ${ }^{2}$, Nikitha Sirigere ${ }^{3}$ \\ ${ }^{1}$ PhD Scholar, Assistant Professor, Dept. of Prasooti tantra and Stree Roga, GAMC, Bangalore, Karnataka, India \\ ${ }^{2}$ Principal and Professor, Dept. of Prasooti tantra and Stree Roga, SDMCA, Udupi, Karnataka, India \\ ${ }^{3}$ Associate Professor, Dept. of Prasooti tantra and Stree Roga, GAMC, Bangalore, Karnataka, India
}

Corresponding Author: dr.nooramina@gmail.com

https://doi.org/10.46607/iamj1209052021

(Published Online: May 2021)

Open Access

(C) International Ayurvedic Medical Journal, India 2021

Article Received: 16/04/2021 - Peer Reviewed: 04/05/2021 - Accepted for Publication: 05/05/2021

Check for updates

\begin{abstract}
Asrigdhara/ Raktapradara is one among the Artavavyapath mentioned by our Acharyas. It can be a symptom in any disease or a disease in itself. The Tridoshakara nidanas mentioned in our classics leads to the manifestation of the disease, the pre-existing Srotodushti in the Garbhashaya and Artavavaha srotas. Any uterine bleeding outside the normal volume, duration, regularity or frequency outside of pregnancy is considered abnormal uterine bleeding (AUB). Heavy menstrual bleeding defines prolonged or heavy cyclic menstruation. Objectively menstruation lasting longer than 7 days or exceeding $80 \mathrm{~mL}$ of blood loss are determining values. The causes of AUB can either be structural (PALM- Polyp, Adenomyosis, Leiomyoma, Malignancy) or non- structural (COEIN- Coagulopathy, Ovulatory dysfunction, Endometrial, Iatrogenic and Not yet classified). Abnormal uterine bleeding among women has a global prevalence of between 3-30\% accounting for about one third of outpatient gynecology visits. This condition affects the quality life of women with socioeconomic and psychological well-being. The Nidanas, Samprapti of Asrigdhara and pathophysiology of abnormal uterine bleeding has been elaborately discussed in the present article which is need of the hour.
\end{abstract}

Keywords: Asrigdhara, Artavavyapath, Tridoshakara nidanas, Artavavaha srotas, Abnormal uterine bleeding. 


\section{INTRODUCTION}

Menstruation refers to the normal process of cyclical uterine bleeding that occurs in the reproductive years of the human female. The process is the result of a carefully orchestrated systemic endocrine relationship involving the hypothalamus, the pituitary, and the ovary that results first in follicular maturation, then ovulation and finally in the absence of conception and implantation with sloughing of the superficial endometrium. The existence of a contiguous pathway that starts in the endometrial cavity and extends to the cervical canal and vagina that allows the components of the menstrual discharge to be externalized. The onset of true menstruation is initiated by the withdrawal of ovarian estradiol and progesterone, while cessation of each episode of menstrual flow seems to be largely a local function, with the endometrium itself responsible for the production of many of the factors required for endometrial hemostasis. ${ }^{1}$

The clinical entity 'Asrigdhara' having excessive or prolonged flow of Asruk during menstruation with or without bleeding in intermenstrual period. It is one among the Rakta pradoshaja vikara ${ }^{2,3,5}$, symptoms of Pitta avruta apana vayu ${ }^{6,7,8}$, Yoni vyapat upadrava 9,10,11 and Artava ativruddhi lakshana ${ }^{12}$. Asrigdhara is classified under four i.e., Vataja, Pittaja, Kaphaja and Sannipataja. ${ }^{13,14,15,16,17}$

Abnormal uterine bleeding is common, and etiologies include anatomic changes, hormonal dysfunction, infection, systemic disease, medications, and pregnancy complications. ${ }^{18}$ The newer classification system is known by the acronym PALM-COEIN (FIGO2011). Polyp, adenomyosis, leiomyoma, malignancy and coagulopathy, hyperplasia, ovulatory dysfunction, endometrial, iatrogenic, and not get classified are the different etiological factors expressed by one (or more) letters. ${ }^{19}$

\section{Samanya Hetu and Samprapti:}

According to Acharya Charaka, excessive consumption of Lavana (salt), Amla (sour), Guru (heavy), Katu (hot), Vidahi (producing burning sensation), Snigdha (unctuous substance), Mamsa of Gramya, Anupa and Aoudhaka Medyani (meat of domestic, marshy, aquatic and fatty animals), Krushara (olio made with rice and pulses), Payasa (rice cooked with milk), Dadhi (curd), Shukta (vinegar), Mastu (curd water) and Madhya (wine) etc. aggravates Vataadi doshas. The aggravated Vayu withholding vitiated Rakta Dhatu due to the above said Nidana's, increases its amount and then reaching the Rajovaha sira's (branches of uterine and ovarian vessels) which further increases the amount Raja (menstrual blood). This increase in menstrual blood is due to its relative increase of Rasa (plasma contents). The quantitative increase in amount of Asruk (menstrual blood), is called Asrigdhara and due to excessive discharge of Raja (menstrual blood), is termed as Pradara. ${ }^{20}$

Table 1: According to Acharya Charaka, the effect of Nidana's on Doshas and Dushyas. ${ }^{21}$

\begin{tabular}{|l|l|}
\hline Atilavana rasa & $\begin{array}{l}\text { Causes Kapha Vishyandana, Raktapittaprakopaka, Mamsa } \\
\text { vidaha, Dhatu Kshaya }\end{array}$ \\
\hline Atiamla rasa & Leads to Pitta Vruddhi, Rakta Dushti, Mamsa Vidaha \\
\hline Atikatu rasa & $\begin{array}{l}\text { Raktasravaka because it is acting as Shonithasanghata } \\
\text { bhedana, Karshayati, Murchayati, Tamayati, Bhramayati, Agni } \\
\text { Bahulya. }\end{array}$ \\
\hline Vidahi aahara & Leads to Pittaprakopaka, Rakta Dushti, Dhatu Shithilata \\
\hline Atisnigdha aahara & Increases Kapha and Medho Dhatu, Jala Mahabhuta Pradhana \\
\hline Guru aahara & $\begin{array}{l}\text { Vitiates Kapha Dosha, Medovruddhikara, Malapramana } \\
\text { vruddhi, Pritvi and Jala mahabhuta pramana }\end{array}$ \\
\hline Krushara (Tila Annam Dwidalamishrita anna, Khichadi) & Gurutva, increases Pitta and Kapha dosha, Vishtambha \\
\hline
\end{tabular}




\begin{tabular}{|l|l|}
\hline $\begin{array}{l}\text { Payasa (Atapta Tandulodouta Paribhrushta } \\
\text { Ghrutenacha. Khandayuktena Dugdhena Paachita } \\
\text { Payaso Bhavet). }\end{array}$ & Vitiates Kapha Dosha, Vishtambhikara, Guru \\
\hline Dadhi & $\begin{array}{l}\text { Increases Medo Dhatu, Kapha and Pitta Dosha, } \\
\text { Abhishyandhikara, Rakta Dushana, Vidahikrut. }\end{array}$ \\
\hline Shukta (Kanjikam) & $\begin{array}{l}\text { Teekshna, Ushna, Lavana and Katu Rasa, increases Pitta } \\
\text { Dosha, }\end{array}$ \\
\hline Mastu(Dadhijalam, Dwigunavaariyutam Dadhi) & Ushna, Amla rasa, increases Pitta Dosha and Sara Guna. \\
\hline Sura & Raktapitta Prakopaka \\
\hline Gramya,Anupa, Aoudaka,Medyani Mamsa & $\begin{array}{l}\text { Vitiates Kapha \& Pitta Dosha, increases Mamsa and Medho } \\
\text { Dhatu. }\end{array}$ \\
\hline
\end{tabular}

Acharya Harita says that the milk carrying channels in Vandhya (infertile women) is filled with Vata, hence there is absence of milk secretion leading to excessive menstrual flow. ${ }^{22}$ Acharya Bhela opines that if Shonita (Rakta dhatu) moves to abnormal passage, it results in Pradara. ${ }^{23}$ Acharya Madhava, Bhavaprakasha, Yogaratnakara says consumption of Viruddha Aahara (incompatible diet), Madhya (wine), Adhyashana (eating before the previous meal is digested), Ajirna (indigestion), Garbhapata (miscarriage), Atimaithuna (excessive indulgence in sexual intercourse), Yana (travelling), Atiadwa (walking), Shoka (grief), Atikarshana (emaciation), Bhara (weight lifting), Abhigaata (trauma), Diwaswapna (day sleep) are causes of Asrigdara. ${ }^{24,25,26}$

Pathophysiology of abnormal uterine bleeding:

Blood reaches the uterus via the uterine and ovarian arteries. From these, the arcuate arteries arise to supply the myometrium. These in turn branch into the radial arteries, which extend the endometrium at right angles from the arcuate arteries. At the endometrium- myometrium junction, the radial arteries bifurcate to create the basal and spiral arteries. The basal arteries serve the basalis layer of the endometrium and are relatively insensitive to hormonal changes. The spiral arteries stretch to supply the functionalis layer and end in a subepithelial capillary plexus. ${ }^{27}$

Physiologic menstruation results from self - destruction of the endometrial functionalis and the shedding of its remains. Throughout the luteal phase, progesterone suppresses release and production of enzymes that can bring about the auto digestion of the functionalis. In the absence of pregnancy, at the end of the luteal phase, progesterone levels drop and its endometrium - protecting effects are lost.

During the preceding luteal phase, progesterone suppresses expression of matrix metalloproteinases (MMPs), an action mediated by transforming growth factor beta (TGF-B). The MMPs are a large family of enzymes that, in the absence of progesterone, digest the components of the extracellular matrix, leading to structural breakdown of the endometrial functionalis. With the loss of progesterone support, intracellular lysosomes rupture, releasing their destructive enzymes contents. These enzymes digest all cellular contents as well as surface membranes.

Contributing further to the degradation of the endometrium, is an inflammatory reaction that results from leukocyte- attracting chemokines released by the endometrial cells. Analogous to the regulation of MMPs, Progesterone suppresses chemokines formation until the progesterone levels dwindle with the end of the luteal phase. Leukocyte infiltration is the final histologic change noted just prior to menses. The invading leukocytes further contribute to the supply of proteolytic enzymes that degrade the extracellular matrix, as well as signalling apoptosis within the cells of the functionalis. With the destruction of the overlying layers that they were supplying the basilar arteries instead lead to blood loss directly into the endometrial cavity. Blood loss continues until epithelium reforms over the basalis. This occurs during the first few days of the proliferative phase of subsequent cycle. Arterial vasoconstriction, mediated by endothelins and prostaglandins, helps to limit blood loss. 
Clotting of blood at the basilar surface also helps to decrease blood loss. This clotting is partially prevented by plasminogen activators that are released from the endometrial tissue during its destruction. They increase the conversion of plasminogen to plasmin, which disrupts the formation of clots. This accounts for the non- coagulability of menstrual blood. Plasmin functions to cleave and activate MMP proenzymes. ${ }^{28}$

\section{DISCUSSION}

This can be understood as extraoral distribution of taste receptors, expression of bitter, sour, salty and pungent taste receptor elements and other chemo sensorial transducers in uterus and ovary. Extra oral taste cellrelated elements that are mainly solitary or clustered cells, not grouped in buds, may be part of a large diffuse chemosensory system compared with an iceberg, the taste buds representing only the most visible portion, while the extraoral taste cells are the larger "submerged" part. Diffuse chemosensory system seems to be involved in cell proliferation, relaxation/contraction of muscles and vessels.TRP (transient receptor potential channel)-mediated vasodilation is induced by various dietary pungent agonists (e.g., carvacrol from oregano-TRPV3 agonist, eugenol from cloves-TRPV4 agonist), as well as by heat, and several mechanisms are involved (e.g., decrease in the intracellular $\mathrm{Ca} 2+$ of arterial myocytes, stimulation of nitric oxide, prostaglandin I2-PGI2, and endothelium-derived hyperpolarizing factor, EDHF production in endothelial vascular cells). Types of TRP (transient receptor potential channel) vanilloid are 1, 3, and 4 (TRPV1, TRPV3, and TRPV4). ${ }^{29}$

Foods such as curd, banana and pineapple are avoided for heavy bleeding. Sour foods like tamarind and pickles were also avoided for fear of heavy bleeding and stomach ache. The menstruating girls were also advised to exclude spices, chilli, and pepper due to the belief that these foods will cause stomach cramps. Sharma and Kaur reported that during menstruation girls are advised to avoid hot foods such as goat meat, eggs and chicken as it is believed that this would cause more bleeding. ${ }^{30}$
Greater consumption of dairy products and foods from animal origin contains measurable amounts of steroid hormones including estrogens. Dairy products accounts for $60-80 \%$ of the estrogens consumed mainly in the form of estrone sulfates. Water soluble estrone sulfate has a high oral activity, and once inside the body it can be converted to estrone and estradiol. Unopposed estrogens increase mitotic activity in endometrial cells and also increases serum levels of insulin like growth factor. ${ }^{31}$

In human females, alcohol ingestion, even in small amounts is insufficient to cause major damage to the liver or other organs and may lead to menstrual irregularities. The effects of estrogen on reproductive cyclicity are complex. In some situation estrogen stimulates the hypothalamic - pituitary unit; in other situations, it is inhibitory. Heavy alcohol intake leads to increase in estrogen production, increase in testosterone levels, increased aromatization of testosterone to estradiol, reduced levels of progesterone and also disrupt reproductive cyclicity by diminishing insulin growth factor-1 neuroendocrine stimulation. ${ }^{32,33}$

Krushara which is prepared contains high levels of unsaturated and polyunsaturated fatty acids which if taken in excess have anti- thrombotic and vasodilatory properties. $\gamma$ - tocopherol is the major tocopherol in sesame seeds whereas $\alpha$ - and $\delta$ - tocopherols are present in smaller amounts. It is more potent than $\alpha$ tocopherol in decreasing platelet aggregation and delaying intra- arterial thrombus formation. ${ }^{34}$

The milk carrying channels in Vandhya is filled with Vata, hence there is absence of milk secretion leading to excessive menstrual flow. This can be understood as excessive prolactin secretion decreases the pulsatile release of gonadotropin releasing hormone impairing the pituitary production of follicle stimulating hormone and luteinizing hormone. It may directly impair the endocrine activity of ovarian follicles. As a consequence: defective luteal phase, inconstant ovulation and chronic anovulation are conditions frequently observed in young hyperprolactinemic patients. ${ }^{35}$ Prolactin - producing pituitary tumors causes menorrhagia by disrupting gonadotropin releasing hormone secretion. This leads to decreased luteinizing hormone and follicle 
stimulating hormone levels, which ultimately cause hypogonadism. Interim stages of menorrhagia result until hypogonadism manifests. The most common etiology of heavy uterine bleeding is anovulatory cycles. ${ }^{36}$

The hypothalamic-pituitary-adrenal (HPA) axis exerts profound, multilevel inhibitory effects on the female reproductive system. First, cortisol suppresses pituitary LH and ovarian estrogen and progesterone secretion, and renders target tissues resistant to E2. Therefore, elevated cortisol levels are known to be responsible for menstrual disturbance caused by stress, as observed in persons with anxiety, depression, malnutrition, eating disorders and chronic exercise. ${ }^{33}$ Dysfunctional uterine bleeding following abortion due to hyperstimulation of the ovary by the pituitary hormones may be responsible factor. Trauma due to intrauterine contraceptive device in utero can lead to menorrhagia due to congestion, increased surface area, or hyperplasia of the endometrium. ${ }^{37}$ Excessive coitus, engaging in careers that involve prolonged standing or heavy lifting can lead to pelvic congestion syndrome which in turn can lead to menorrhagia and menometrorrhagia occur in up to 54\% of patients. Psychiatric disturbances usually of emotional character can lead to pelvic congestion. ${ }^{38,39}$

When the delicate balance between high-load exercise sessions and adequate recovery periods is disrupted, excessive training (known as overtraining) can lead to performance decline. The cytokine hypothesis considers that an imbalance involving excessive exercise and inadequate recovery induces musculoskeletal trauma, increasing the production and release of proinflammatory cytokines, mainly interleukin 6 (IL-6), tumor necrosis factor-alpha (TNF-alpha), and interleukin lbeta (IL-1 beta), which interact with different organic systems, initiating most of the signs and symptoms linked to performance decrement. ${ }^{40}$

The study was conducted to report the frequency of abnormal day sleep and identifies factors related to day sleep, night sleep disturbances, and circadian rhythm abnormalities among nursing home residents. $69 \%$ of 492 observed residents had day sleep, of whom $60 \%$ also had disturbed night sleep. Residents spent $1 / 3^{\text {rd }}$ of the day in their rooms, typically in bed, were seldom outdoors or exposed to bright light. More time in bed and less social activity were significant predictors of day sleep. $97 \%$ or residents assessed had abnormal circadian rhythms. More day sleep and less night sleep were associated with weaker circadian activity rhythms. Later circadian rhythm acrophase (peak) was associated with more bright light exposure. ${ }^{41}$

Disruption of circadian rhythms is associated with disturbances in menstrual function. Female shift workers compared to non-shift workers are more likely to report menstrual irregularity and longer menstrual cycles. ${ }^{42}$

Impact of Junk food on menstruation, apart from forming plaques and constricting arteries cholesterol also affects liver where it is metabolized. High cholesterol due to junk food and diet strains liver damaging it finally. This is long term effect. Junk food diet is a major cause of heart diseases (Myocardial infarction) due to plaque formation in arteries which demands heart to put in extra effort to pump blood on the downstream, on the upstream there is lack of returning blood to heart, this causes two damages to heart - heart fatigues due to continuous extra effort and it suffer in oxygen supply.

The nutritional value of junk food is about one on a scale of 1 to 10 , which is the least. The nutritional value is lost in the process of making the junk food so synthetic vitamins and minerals are added to compensate it, but they are not good compared to natural vitamins and minerals. Natural phytochemicals are not present in junk food which soaks up the free radicals to prevent disease. It is well known fact that fat and sugar are as addictive as heroin and cocaine, they stimulate the same receptors in the brain that make feel good due to increased dopamine level. Junk foods have a lot of hidden sugar and fat to make it addictive and also enhance the taste.

Junk food have lots of chemical additives which are not useful to body, things are like artificial coloring and preservatives. Monosodium glutamate (MSG) and tartrazine is in almost all type of junk food and all sorts of medical studies have revealed that MSG causes obesity and of other nasty things. All the techniques used to process the junk food - canning, dehydrating and freezing, virtually destroy the flavor of food so chemicals under the guise of 'natural flavor' have been added to enamel the flavor, while color additives are added to 
make food fresh. It might make the food look and taste better, but it is harmful to our bodies. Junk food is rich in fat so accumulation of fat can take place in bronchioles so oxygen supply tends to reduce in body which can cause some respiratory disorders. ${ }^{43}$

The disease is characterized by excessive prolonged bleeding during menstruation with or without intermenstrual bleeding. Due to Nidana Sevana, Dosha Prakopa takes place which leads to Agnimandhya, Vaikruta Aahara Rasa Pramana Vruddhi, Rasadhatwagni Vaishamya, Vikruta Rasa Dhatu Utpatti, Upadhatu Artava Vruddhi, Rajovaha Samashrita Garbhashayagata Sirah, Apana Vayu Dushti leading to Asrigdhara.

All the Tridoshas are vitiated with the above said $\mathrm{Ni}$ danas, due to Vatakara Nidanas, the vitiated Vata Dosha, with Apana Vata Vikruti which performs Artava Pravrutti along with Chala Guna of Vata carries Pitta and Kapha Doshas, Dhatus and Malas. Vyana Vata helps in the circulation of Rasa and Rakta Dhatu all over the body. Akunchana, Prasarana and Akshepana helps in extension, contraction and downward movement etc. Hence, any Vikruti of Vata Dosha causes excessive bleeding during menstruation.

Pitta Dosha made up of Agni and Jala Mahabhutas, its Gunas- Snigdha, Teekshna, Ushna, Laghu, Visram, Sara, Dravam is located in Rudhira and Rasa. Pitta located in Rasa Dhatu, by its Dhatavagni Guna gets transformed into Rakta by its Raga and Ushna Gunas. Agni in Pitta provides Ushnata, Pitta in turn adds Ushnata to the Rakta.

Due to Pittakara Nidana, Pittaprakopa takes place and gets Sthanasamshraya in Rakta Dhatu because of Ashraya Ashrayi Bhava. By Ushna Guna of Pitta, Dushana of Rakta Dhatu occurs along with Ksharana of Dravamshana in other Dhatus. The increase in Drava Roopa and Sara Guna, in Raktavaha Srotas and Artava- the Upadhatu of Rasa, with the pre - existing Artavavaha Srotodushti, leading to Atipravrutti of Artava. Kapha Dosha is made up of Jala and Pritvi Mahabhuta. The Gunas like Snigdhatva, Gurutva and Picchilatva is vitiated located in Rasa, Mamsa and Meda causing endometrial hyperplasia which leads to irregular ripening and shedding of endometrium.
The concept of Pittavruta Apana Vata, where Apana Vata is obstructed by vitiated Pitta, resulting in aggravated symptoms of Pitta Dosha. This declines the normal functioning of Apana Vata. ${ }^{44}$

Srotovaigunya plays a vital role for the Sammurchana of Dosha and Dushyas at a particular site as a result disease manifest. The Aahara and Vihara which aggravates the Doshas having the properties opposite to dhatus vitiates the Srotas. Dhatwantharadusti, there is structural vitiation and vitiation in Srotas. More than one Srotas is involved in the vitiation of disease. The manifestation of Srotodushti, Atipravrutti - it is defined as Atishayenapravrattihi. Increased activity of one or more Dhatus, Doshas, Srotas, Malas. ${ }^{45}$

In the concept of Rakta Pradoshaja Vikaras, the Rakta Dhatu Vruddhi takes place due to the use Aahara and viharas which are of Samana Guna (possessing similar properties) leading to the manifestation of Raktapradara. $^{46}$

The endometrium's significant prostaglandin content is released during the destruction of the functionalis layers. Prostaglandin with arterial vasoconstriction, cause myometrial contraction. Endothelin -1 and $\mathrm{PGF}_{2 \alpha}$ stimulate local vasoconstriction, both $\mathrm{PGE}_{2}$ and $\mathrm{PGI}_{2}$ (prostacyclin) cause vasodilatation of endometrial vessels with $\mathrm{PGI}_{2}$ also a potent natural inhibitor of platelet aggregation. Increase in the local levels of cyclooxygenase, the enzyme that catalyzes the conversion of arachadonic acid to prostaglandin precursors, increased synthesis of $\mathrm{PGE}_{2}$ compared with $\mathrm{PGF}_{2 \alpha}$ and increased expression of $\mathrm{PGE}_{2}$ receptors. There is also a local increase in the synthetic capacity for $\mathrm{PGI}_{2}$ and the number of $\mathrm{PGI}_{2}$ receptors. Both individually and collectively, contribute to a reduction in the ability of the endometrium to attain effective haemostasis. The process of clot breakdown - if lysis of the clot occurs too quickly leading to enhanced fibrinolysis, through increased endometrial levels of tissue plasminogen activator. Increased synthesis of heparin like activity may contribute to reduction in local haemostasis. Increasing levels of tumor necrosis factor- $\alpha$ and reduction in the measured levels of vascular endothelial growth factor A and matrix metalloproteinase matrix -2 and MMP 9. 
A novel gene called "endometrial bleeding associated factor" (EBAF, also known as LEFTY-A) is transiently expressed in normal endometrium at menstruation and much more strongly expressed in heavy menstrual bleeding. This gene is located on chromosome 1 and codes for a member of the TGF- $\beta$ super - family.

Increased uterine contractility is associated with decreased endometrial blood flow and also uterine artery pulsatility index is highest on the first day of menstruation when myometrial activity is highest. These findings indicate that reduced basal tone or contractility decreases the compression of vessels traversing the uterine wall, resulting in decreased resistance to flow.

Changes in relationship between serum and local concentrations of vasoactive compounds such as prostaglandins, endothelins and prostacyclins may be associated with uterine flow impedance in the endometrial vascular bed. The menstrual blood loss is thought to be determined by the balance between vasoconstrictor prostaglandin $\mathrm{F}_{2 \alpha}\left(\mathrm{PGF}_{2 \alpha}\right)$ and the vasodilators prostaglandin $\mathrm{E}_{2}\left(\mathrm{PGE}_{2}\right)$ or prostaglandin $\mathrm{I}_{2}\left(\mathrm{PGI}_{2}\right)$. In menorrhagia, the endometrial uptake of arachidonic acid is increased and conversion of exogenous arachidonic acid to $\mathrm{PGE}_{2}$ or prostacyclin is enhanced. Both dilate the blood vessels and inhibit platelet accumulation, thus increasing uterine bleeding. This could well lead to decreased impedance of the uterine artery. The immunocytochemical localization of endothelins - like immunoreactivity in basal endometrium suggests that these potent peptides may not only be candidates for the endometrial vasoconstrictor, but may also be involved in the mediation of uterine contractions and endometrial proliferation, thus possibly interfering with the uterine blood flow. ${ }^{47}$

Growth factors stimulate angiogenesis, the growth of new blood vessels, which follows menstruation. Women with menorrhagia show a significant increase in endothelial cell proliferation, reflecting disturbed angiogenesis. Studies utilizing light microscopy have demonstrated ectasia (dilatations)of the venules in both the myometrium and endometrium of uteri containing leiomyoma, which is associated with menorrhagia. In abnormal vessels (vascular abnormalities), poor contractility and dysfunction of the haemostatic system may cause menorrhagia and decreased impedance. The uterine artery besides giving vascularity to the uterus, also provides a branch to the ipsilateral ovary, fallopian tubes and upper vagina. ${ }^{48}$

The endometrial haemostasis which is responsible for cessation of menstrual bleeding involves platelet aggregation, fibrin deposition and thrombus formation. Studies of myometrium have traditionally been limited to the pregnant uterus and labor, although myometrial contractions felt as menstrual period associated 'cramps' are a symptom that is commonly reported by women during menstruation. This dramatic increase in the amplitude (labor like, and increased from a base line of $<30 \mathrm{mmHg}$ up to $50-200 \mathrm{mmHg}$ ) of myometrial contractility, particularly seen in the inner subendometrial zone of the myometrium during menstruation, is likely to be induced by increased endometrial production of prostaglandins such as $\mathrm{PGF}_{2 \alpha}$ and $\mathrm{PGE}_{2}$. These contractions may play a role in emptying the uterine cavity of menstrual debris and may also play a haemostatic role by providing a pressure effect on the endometrial vasculature. The pivotal role played by myometrial contractility in preventing uterine bleeding following parturition is well established, very little is known of the contribution of myometrial contractility in regulation of menstrual bleeding. ${ }^{49}$

\section{CONCLUSION}

Nidanas performs multidimensional action in the initiation and manifestation of the disease process by aggravating Vataadi Doshas. It is culprit to bring in equilibrium of Doshas, Dushyas etc and disturbs the normal physiological functions for the production of disease. Asrigdhara is the is the disease caused by the vitiation of Tridoshas characterised by excessive or prolonged bleeding during menstruation which can be clinically correlated with causes of abnormal uterine bleeding. The causative factors and pathophysiology of and heavy menstrual was given a correlation.

\section{REFERENCES}

1. Munro M. Abnormal uterine bleeding. 1st ed. Cambridge: Cambridge university press; 2010. 
2. Acharya Yadavji Trikamji, editor. Charakasamhita of Agnivesha, Sutrasthana, $3^{\text {rd }}$ edition. Ch $24^{\text {th }}$, ver 11-12. Varanasi: Chaukhamba Sanskrit sansthana; 2013.p-124

3. Acharya Yadavji Trikamji, editor. Sushrutasamhita of Sushruta, Sutrasthana, $9^{\text {th }}$ edition, Ch $24^{\text {th }}$, ver 9 . Varanasi; Chowkhamba Orientalia; 2012.p- 116

4. Acharya Anant Damodar Aatwale, editor. Ashtanga Sangraha of Vagbhata, Sutra sthana, Ch $19^{\text {th }}$, ver 7 , Pune, Atreya Prakashan, 1980, p-140

5. Acharya Tewari PV, Kashyapa Samhita of Vrudda Jeevaka, , Sutra sthana, $27^{\text {th }}$ chapter, verse 63 , Varanasi, Choukhambha Visvabharati ,2002, p- 73

6. Acharya Yadavji Trikamji,editor. Charakasamhita of Agnivesha, Sutrasthana, $3^{\text {rd }}$ edition. Ch $28^{\text {th }}$, ver 230.Varanasi: Chaukhamba Sanskrit sansthana; 2013.p-626

7. Acharya Sadashiva shastri Paradakara, editor. Astanga Hrudaya of Vagbhata, Nidana sthana, Ch $16^{\text {th }}$, ver 45 . Varanasi, Chaukhamba Surbharati Prakashan, 2014.p539

8. Acharya Yadavji Trikamji, editor. Sushrutasamhita of Sushruta, Sutrasthana, $9^{\text {th }}$ edition, Ch $1^{\text {st }}$, ver 37 . Varanasi; Chowkhamba Orientalia; 2012.p- 263

9. Acharya Yadavji Trikamji, editor. Charakasamhita of Agnivesha, Sutrasthana, $3^{\text {rd }}$ edition. Ch $30^{\text {th }}$, ver 39 . Varanasi: Chaukhamba Sanskrit sansthana; 2013.p-636

10. Acharya Anant Damodar Aatwale, editor. Ashtanga Sangraha of Vagbhata, Uttara sthana, Ch $38^{\text {th }}$, ver 57, Pune, Atreya Prakashan, 1980, p-831

11. Acharya Sadashiva shastri Paradakara, editor. Astanga Hrudaya of Vagbhatta, Uttara Sthana, Ch $33^{\text {rd }}$, ver 52, Varanasi, Chaukhamba Surbharati Prakashan, 2014, p896

12. Acharya Yadavji Trikamji, editor. Sushrutasamhita of Sushruta, Sutrasthana, $9^{\text {th }}$ edition, Ch $15^{\text {th }}$, ver 16. Varanasi; Chowkhamba Orientalia; 2012.p- 70

13. Acharya Yadavji Trikamji, editor. Charakasamhita of Agnivesha, Chikitsa sthana, $3^{\text {rd }}$ edition. Ch $30^{\text {th }}$, ver 210. Varanasi: Chaukhamba Sanskrit sansthana; 2013.p-643

14. Acharya Madhavakara. Madhava nidanam. (29 ed.). Varanasi: Chaukhambha Sanskrit Sansthana; Ch $61^{\text {st }}$, ver $1,2000, p-755$

15. Bhishagratna shri Brahma Shankaramishra shaastri, editor.Acharya Bhavamishra, Bhavaprakasha, Varanasi: Chowkhamba Sanskrit series, Chikitsa sthana, Ch $68^{\text {th }}$, ver 2, 2018, p-755

16. Anonymous ,Yogaratnakara, Varanasi: Chaukhambha Prakashan, Stri roga adhikara, ver 2, 2013,p-396
17. Acharya Sharangadhara, Sharangadhara samhita,(6th ed.). Varanasi: Chaukhambha Orientalia, Purvakhanda, Ch 7th, ver 176, 2005, p- 126

18. Hoffman B, Schorge J, Bradshaw K, Halvorson L, Schaffer J, Corton M. Williams Gynecology. 3rd ed. New York: Mc Graw Hill; 2016.

19. Dutta D. Textbook of gynecology. 6th ed. New Delhi: Jaypee Brothers Medical Publishers; 2013.

20. Acharya Yadavji Trikamji, editor. Charakasamhita of Agnivesha, Chikitsa sthana, $3^{\text {rd }}$ edition. Ch $30^{\text {th }}$, ver 204209. Varanasi: Chaukhamba Sanskrit sansthana; 2013.p-642, 643

21. Professor Madanmohan Jha, editor. Shabdakalpadruma of Raja Radhakanthdev, New Delhi: Naga publishers; p$10,180,680$

22. Acharya Vaidya Jaymini Pandey, editor. Haarita Samhita of Haarita, (1ed), Varanasi, Chaukhambha Visvabharati, Prathama Sthana, Ch $8^{\text {th }}$, verse 10, 2010, p- 62

23. Acharya Priya Vrta Sharma, editor. Bhela Samhita of Bhela, (1 ed), Varanasi, Chaukhambha Visvabharati, Sharira sthana, Ch $6^{\text {th }}$, ver $7^{\text {th }}, 2000, \mathrm{p}-223$

24. Madhavakara. Madhava nidanam. (29 ed.). Varanasi: Chaukhambha Sanskrit Sansthana; Ch $61^{\text {st }}$, ver 1, 2000, p-755

25. Bhishagratna shri Brahma Shankaramishra shaastri, editor. Acharya Bhavaprakasha of Bhavamishra, Varanasi, Chowkhamba Sanskrit series, Chikitsa sthana, Ch $68^{\text {th }}$, ver 1, 2018, p-755

26. Anonymous ,Yogaratnakara, Vidyotini Hindi commentary by Vaidya Lakshmipati shastri, Varanasi ,Chaukhambha Prakashan, 2013,Stri roga adhikara,verse-1,p- 396

27. Hoffman L, Schorge O, Bradshaw D, Halvorson M, Schaffer I et al. Williams Gynaecology. (3 ed.). United States: Mc Graw Hill Education; 2016.

28. Zinger M. Physiology of menstruation. In: O' Donovan P, E Miller C, ed. by. Modern management of Abnormal uterine bleeding [Internet]. UK: Informa health care; 2008 [cited 30 December 2020]. p. 15. Available from: https://www.pdfdrive.com

29. Gilca M, Dragos D. Extraoral Taste Receptor Discovery: New Light on Ayurvedic Pharmacology. Hindawi Evidence-Based Complementary and Alternative Medicine. 2017; pages 30 .

30. Goswami R, Thakur M. Folk beliefs of food avoidance and prescription among menstruating and pregnant Karbi women of Kamrup district, Assam. Journal of Ethnic Foods [Internet]. 2019 [cited 3 April 
2021];6(19):1-7. Available from: https://doi.org/10.1186/s42779-019-0013-7.

31. Ganmaa D, Cui X, Feskanich D, E Hankinson S, C Willett W. Milk, dairy intake and risk of endometrial cancer: a 26 -year follow up. International Journal of Cancer. 2012;130: 2664-2671.

32. Emanuele M, Wezeman F, V Emanuele N. Alcohol's effects on female reproductive function, Alcohol research and health: the journal of the national institute on alcohol abuse and alcoholism. 2002;26(4):274-81.

33. S Gavaler J, H Van Thiel D. Reproductive consequences of alcohol abuse: Males and females compared and contrasted. Mutation research/ reviews in Genetic Toxicology,1987;186(3):269-277.

34. Pathak N, Rai A, Bhat K, Kumari R. Value addition in sesame: A perspective on bioactive components for enhancing utility and profitability. Pharmacognosy reviews [Internet]. 2014 [cited 15 March 2021];8(16):147155. Available from: https://www.researchgate.net/publication/264794862

35. Crosignani P. Management of hyperprolactinemic infertility. Middle East Fertility Society Journal. 2012;17(2):63-69.

36. www.medscape.com

37. Perry C. Current concepts of pelvic congestion and chronic pelvic pain. Journal of the society of laparoscopic and robotic surgeons. 2001;5(2):105-110.

38. Philips D, R Deiopolyi A, L Hesketh R, Midia M, Oklu R. Pelvic congestion syndrome: Etiology of pain, diagnosis and clinical management. Journal of Vascular and interventional radiology. 2014;25(5):725-733.

39. Joon Cho G, Won Han S, Ho Shin J, Kim T. Effects of intensive training on menstrual function and certain serum hormones and peptides related to the female reproductive system. Medicine. 2017;96(21):1-6.

40. L Da Rocha A, P Pinto A, B Kohama E. The proinflammatory effects of chronic excessive exercise. ScienceDirect. 2019; 119: 57-61.

41. Martin JL, Webber AP, Alam T, Harker JO, Josephson KR, Alessi CA. Daytime sleeping, sleep disturbance and circadian rhythms in the nursing home. American Journal Geriatric psychiatry. 2006;14(2):121-9.

42. C Baker F, S Driver H. Circadian rhythms, sleep, and the menstrual cycle. ScienceDirect. 2007;8(6):613-622

43. Rajveer B, Monika O. Junk food: impact on health. Journal of Drug Delivery \& Therapeutics; [Internet]. 2012 [cited 1 April 2021];2(3):67-73. Available from: http://jddtonline.info
44. Lakshmi K, Shashirekha. A critical understanding of Ashraya-ashrayi bhava. Ayushdhara. 2017;4(2): 11071110 .

45. Gayathri, H, Byresh, A. Srotovaigunya, srotodushti and srotoviddha - A conceptual study. International Ayurvedic Medical Journal. 2017;5(7): 2517-2524.

46. Acharya Anant Damodar Aatwale, editor. Ashtanga Sangraha of Vagbhata, Sutra sthana, Ch $19^{\text {th }}$, ver 7 , Pune, Atreya Prakashan, 1980, p-140

47. Munro M. Abnormal uterine bleeding. 1st ed. Cambridge: Cambridge university press; 2010.

48. Hurskainen R, Teperi J, Paavonen J, Cacciatore B. Menorrhagia and uterine artery blood flow. Human Reproduction [Internet]. 1999 [cited 4 April 2021];14(1):186189. Available from: https://academic.oup.com/humrep/article/14/1/186/588130

49. Hapangama D, Bulmer J. Pathophysiology of Heavy Menstrual Bleeding. Womens Health [Internet]. 2016 [cited 4 April 2021];12(1):3-13. Available from: https://doi.org/10.2217\%2Fwhe. 15.81

\section{Source of Support: Nil Conflict of Interest: None Declared}

How to cite this URL: Noor Fathima et al: Analysis Of Nidanas On Asrigdhara With Special Reference To Pathophysiology Of Abnormal Uterine Bleeding. International Ayurvedic Medical Journal \{online\} 2021 \{cited May, 2021\} Available from: http://www.iamj.in/posts/images/upload/1018_1026.pdf 